\title{
Is it Worth Flipping? The Impact of Flipped Classroom on EFL Students' Grammar
}

\author{
Ishaq Salim Al-Naabi ${ }^{1}$ \\ ${ }^{1}$ English Language Center, Nizwa College of Technology, Oman \\ Correspondence: English Language Center, Nizwa College of Technology, P.O. Box 477, Postal Code 611, \\ Nizwa, Oman.
}

Received: May 1, 2020

Accepted: May 26, 2020

Online Published: May 29, 2020

doi: 10.5539/elt.v13n6p64

URL: https://doi.org/10.5539/elt.v13n6p64

\begin{abstract}
In light of contemporary pedagogical methods, the flipped classroom has been recognised as an effective pedagogy in English as a Foreign Language (EFL). This study employed a quasi-experimental one-group research design to investigate the impact of flipped learning on Omani EFL learners' grammar and to examine students' perceptions on the flipped classroom. An intact group of students $(n=28)$ enrolled at the foundation programme in Arab Open University-Oman was randomly selected. Seven videos on English grammar were developed and shared with the students prior to the class. A varaiety of activities were conducted in the class following task-based language teaching. Students met for 8 lessons over the period of 8 weeks. Pre-test, post-test and semi-structured interviews were used in the study. The findings indicated that flipped learning had a positive impact on students' understanding and usage of English grammar. Students' perceptions on the flipped approach were positive. The study also provided pedagogical insights for the flipped classroom and recommendations for future research.
\end{abstract}

Keywords: EFL, Flipped classroom, grammar, higher education, Oman, perceptions, task-based language teaching

\section{Introduction}

It has become very hard to ignore the role of technology in education nowadays. UNESCO (2014) stressed that life-long learning is a fundamental principle of the post-2015 education agenda, which is achieved by creating a new culture of learning with the assistance of information technologies. Recently, a global call has been raised to transform learners into digital creators of knowledge (Alexander et al., 2017). Due to such calls to integrate technology into classrooms and to equip learners with essential 21st-century skills (Alexander et al., 2017; Bennett \& Lemoine, 2014; Johnson, 2009), flipped learning has recently gained much attention in higher education. Although the flipped classroom methodology has been embraced and successfully adopted by various higher education institutions around the world, research on the effectiveness of the flipped methodology and students' perceptions of the flipped classroom remains very scarce (Abeysekera \& Dawson, 2016; Bishop \& Verleger, 2013; Han, 2015; Kvashnina \& Martynko, 2016; Mcnally et al., 2017; Pierce \& Fox, 2012).

Even though flipped learning has been recognised as a potential methodology in higher education in Omani higher academic institutions (Lane-Kelso, 2015), limited research has addressed flipped learning in the Omani context. The current study, therefore, attempts to introduce a flipped learning approach in the English as a Foreign Language (EFL) classroom in the General Foundation Programme at Arab Open University-Oman (AOU-Oman).

This study aims to answer the following research questions:

1. What is the effect of the flipped learning approach on Omani EFL students' grammar proficiency?

2. What are Omani EFL students' attitudes towards the flipped classroom approach?

\section{Flipped Classroom}

The flipped classroom started in 2006 when two high school chemistry teachers, Jonathan Bergmann and Aaron Sams, video recorded their chemistry lessons for absent students. Their students liked the videos and requested them to record and share more videos. Bergmann and Sams observed that their videos made a positive impact on 
their students and improved their academic achievement (Bergmann \& Sams, 2012).

The flipped classroom methodology involves assigning content materials - such as lecture notes and pre-recorded videos - to students as homework, thus leaving class time for interactive learning activities (Bishop $\&$ Verleger, 2013). As a result, instead of spending the lion's share of class time lecturing and explaining content, the majority of the class time is spent in doing collaborative activities or project- or problem-based language learning (Bauer-ramazani et al., 2016).

In order to flip the classroom, teachers should follow the four pillars of the flipped classroom: flexible environment, learning culture, intentional content and professional educator (Bauer-ramazani et al., 2016). The first pillar, flexible environment, implies that the learning environment must be flexible in time and place. The second pillar, learning culture, refers to the shift in the teaching approach from a teacher-centred approach to a student-centred approach. The third pillar, intentional content, indicates that the aim of flipping the classroom is to develop students' content as well as cognitive skills. Finally, the fourth pillar, professional educator, emphasises the role of teachers in designing excellent lessons, videos and materials, facilitating interactive classroom activities, evaluating and providing feedback to students (Mcnally et al., 2017).

A list of four essential elements of the flipped classroom can be derived from Abeysekera \& Dawson (2016), Brame (2013) and Mcnally et al., (2017):

1. Prior exposure of students to content (e.g. recorded lectures, notes, videos)

2. An incentive for students to prepare for class (e.g. pre-class quizzes, online discussions, online activities)

3. A mechanism to measure students' understanding and to ensure that students have viewed the content (e.g. graded pre-class quizzes)

4. In-class activities that focus on higher-level cognitive activities: active learning, collaborative and peer learning, problem-solving and/or case studies.

Flipped learning is based on some theoretical underpinnings that explain its success and popularity. First, Bloom's Taxonomy is related to flipped classroom because the transmission of information, which is the basic component of learning, is conducted independently by the students outside the classroom and assimilation of information, which requires critical thinking, analysis and synthesis and reasoning, takes part during the class with the guidance of the teacher (Eppard \& Rochdi, 2017). Furthermore, constructivism theory is relevant to flipped learning. Accorrding to constructivism theory, learning is a result of mental construction (Olusegun, 2015), and learners construct their knowledge through experience, interaction and reflection (Bereiter, 1994). This is evident in the flipped classroom when students are assigned problem-solving tasks where they need to utilise the information that was presented to them previously outside and before the class (Eppard \& Rochdi, 2017).

Current research on the flipped classroom has shed light on the benefits and challenges of this teaching method. According to Marshall and DeCapua (2013), using a flipped classroom allows the teacher to spend class time in observation, feedback and assessment. Additionally, the flipped learning approach allows teachers to incorporate collaborative project-based and problem-based learning (Carhill-Poza, 2019). Carhill-Poza (2019) added that flipped learning has the potential to extend communicative language teaching practice by providing learners and teachers with methods that facilitate social mediation. Arifani (2019) claimed that the flipped learning approach enhances EFL students' collaboration. Since the approach hinges on the assumption that learning is personal and that learning occurs in active and interactive environments, the flipped classroom fosters the development of high-order thinking skills (Bergmann \& Sams, 2012; Bishop \& Verleger, 2013).

However, implementing flipped learning may face some challenges, such as 'increased time needed to set up the tools and equipment for technology support, developing appropriate language and assessment activities, finding online resources to support language and content activities, and designing tasks for critical thinking and project-based learning' (Bauer-ramazani et al., 2016, p. 345). Watching videos and reading materials before the class in the flipped learning approach can be an extra homework for students, which can negatively affect student learning in the flipped classroom (Bergmann \& Sams, 2012; Lee \& Wallace, 2018). Internet connectivity problems might hinder the successful implementation of a flipped learning approach (Andujar et al., 2020).

\subsection{Effectiveness of Flipped Classroom}

Although the flipped classroom methodology is a common practice nowadays in many countries around the world, Mcnally et al., (2017) argued that there is a lack of empirical research on the effectiveness of flipped classrooms. Lee and Wallace (2018) studied the impact of the flipped classroom on South Korean EFL university 
students' language skills using three major tasks (two exams, two writing assignments and two presentations). Their results indicated that students in the flipped classroom had higher average scores across the three tasks compared to the non-flipped classroom (Lee \& Wallace, 2018). In an empirical study conducted in Turkey, Köroğlu and Çakır (2017) used a pre- and post-test experimental research methodology to measure the effectiveness of the flipped classroom course on pre-service English language teachers' speaking skill development. They found that students of the experimental group, who had participated in a flipped classroom, developed significantly greater fluency, coherence, lexical resources, grammar, pronunciation and accuracy skills Even though their research yielded positive results regarding the flipped classroom, a key problem in their study was the lack of information on the classroom procedures and samples of the course content. Pudin (2017) conducted a descriptive study to explore the effects of the flipped learning approach in a grammar classroom through the perceptions of 120 first-year Malaysian students in a Malaysian university. The data analysis revealed that the flipped classroom improved students' understanding of grammar. Similarly, Lee's (2017) descriptive research on the effectiveness of flipped learning on South Taiwanese undergraduate English for Specific Purposes (ESP) courses revealed that flipped learning had a positive impact on students' language skills. In another study, Al-harbi and Alshumaimeri (2016) used a quasi-experimental research design to measure the impact of the flipped classroom strategy on Saudi secondary school students' grammar. Their study concluded that students in the experimental group - who were provided with online materials and videos before their classes and were taught grammar using tasks and interactive activities - outperformed the control group students who were taught grammar conventionally. Collectively, these studies emphasise a critical role of the flipped classroom in language instruction, specifically in grammar instruction.

\subsection{Students' Perceptions of Flipped Classroom}

Several studies attempted to gauge students' perceptions on the flipped classroom. Andujar et al. (2020) explored the perceptions of 84 Spanish EFL learners following a flipped learning model in a secondary education school. Although connectivity and video streaming issues were reported in their study, their findings indicated a high overall satisfaction level towards flipped learning (Andujar et al., 2020). Using action research, Lee and Wallace (2018) also investigated South Korean College students' perceptions on flipped learning. Their results indicated that students enjoyed learning English using the flipped classroom, and teachers found students to be more motivated in the flipped classroom (Lee \& Wallace, 2018). Sun (2017) explored undergraduate foreign language students' perceptions of the flipped classroom approach. His study indicated that students possessed a positive attitude towards learning in the flipped classroom because it had a positive impact on their language development. In another attempt to explore pre-service teachers' perceptions after being enrolled in a flipped classroom course in Turkey, Kurt (2017) reported that these pre-service teachers perceived themselves to be highly motivated to learn compared to their peers in traditional classroom settings because of their active participation in both pre-class activities and in-class activities. Kurt (2017) also stated that pre-service teachers felt relaxed and confident in the classroom after being engaged in the materials before the class. Similarly, Al-harbi \& Alshumaimeri (2016) found that students perceived videos in a flipped classroom to be very positively influential in their learning because they could refer to those videos and materials outside the classroom. In another study, Pudin (2017) explored graduate students' perceptions of the flipped learning approach to learning grammar. According to Pudin (2017), students found that the flipped classroom was more engaging than the traditional classroom, provided them with opportunities to interact with other students and enhanced their motivation to learn grammar. Although most students were in favour of flipped learning, Pudin (2017) reported that some students faced initial discomfort at the beginning of the intervention because they were not accustomed to flipped learning. Therefore, he recommended that teachers who are planning to implement flipped learning approaches should consider the discomfort that students might face in adjusting to new pedagogical instruction (Pudin, 2017). Basal's (2015) qualitative research revealed that pre-service English language teachers had positive perceptions toward the use of the flipped classroom. Based on the content analysis of the teachers' responses, the flipped classroom was beneficial for students in four areas: 'learning at one's own pace, advance students' preparations, overcoming the limitations of class time, increasing the participation in the classroom' (Basal, 2015, p. 28). After surveying 101 students at the Australia National University, Butt (2014) found that $75 \%$ of the surveyed students claimed that the flipped classroom was more beneficial to their learning compared to lectures. Lane-Kelso (2015) studied the experiences of master's level students learning with the flipped method at Sultan Qaboos University in Oman. His results showed that participants were motivated to adopt the flipped classroom approach in their schools and institutions because of the benefits of the flipped classroom. However, evidence indicated that despite their positive attitudes towards flipped learning, the participants were reluctant and not ready to apply the flipped classroom to the Omani classroom because flipping 'required [them] to rethink activities and timings and required educating school 
administration, colleagues and parents' (Lane-Kelso, 2015, p. 128). These studies provide strong evidence for positive perceptions of the flipped classroom by students.

\section{Method}

\subsection{Participants}

An entire Level 2 class of the foundation programme at AOU-Oman was randomly selected for the study. The class consisted of 28 students: 26 (92.8\%) female students and $2(7.1 \%)$ male students. Their age ranged from 18 to 20 years. All the students had completed Level 1 (EF001) of the foundation programme at AOU-Oman, which is a pre-requisite before Level 2 (EF002).

In order to assess the English language proficiency of the students in the group, two measures were used: the Oxford Online Placement Test (OOPT), which was administered to all students at their entrance to AOU-Oman, and analysis of their final results in Level 1 (EF001). When tested, the students' English proficiency ranged from 1 to 20 on the Oxford Placement Test. Their average score was 11.2. When matched to the Common European Framework of Reference for Languages (CEFR), their English level was A1 (Basic Level). Second, for further understanding of the students' proficiency in English, their results from Level 1 (EF001) were analysed before the beginning of the intervention. Table 1 shows students' results in Level 1. Students' scores were categorised into four levels: very high (90 to 100$)$, high ( 80 to 89 ), moderate (70 to 79 ), low (60 to 69 ) and very low (50 to 59). Approximately half of the students (48.3\%) had achieved a low level of English proficiency in Level 1, whereas only $10.3 \%$ of the students had demonstrated a high level of language proficiency. Overall, the data presented in Table 1 and the results of the students in the OOPT indicate that students' overall level in English was low.

Table 1. Students' results in level one (EF001) $(\mathrm{N}=28)$

\begin{tabular}{rlcc}
\hline Scores Scale & N & $\%$ \\
\hline $90-100$ & Very high & 0 & 0 \\
$80-89$ & High & 3 & 10.3 \\
$70-79$ & Moderate & 7 & 24.1 \\
$60-69$ & Low & 14 & 48.3 \\
$50-59$ & Very low & 5 & 17.2 \\
Less than 50 & Fail & 0 & 0 \\
\hline
\end{tabular}

\subsection{Context}

AOU-Oman is a private higher education institution in Oman. It offers bachelor's degrees in Business Studies, Administration and Information Technology. It also offers master's degrees in Business Administration, Educational Leadership and Educational Technology. Before their enrolment in the degree programmes, most students are enrolled in the foundation programme to develop their English language skills, Information Technology skills, Mathematics skills and study skills. The English foundation programme at AOU-Oman consists of three levels (Level 1: EF001, Level 2: EF002, Level 3: EF003). Two commercial textbooks are used for each level of the foundation programme. Garnet English Skills for University Level 1 and 2 and Keep Writing Level 1 and Level 2 are used for Foundation Level 1 (EF001) and Foundation Level 2 (EF002). Garnet Progressive Skills in English Level 1 and Better Writing are used for Level 3 students. Different supplementary materials are prepared to meet the learning objectives of the foundation programme. For the intervention, parts of Unit 1 and 2 from the main book and parts of Unit 1 of Keep Writing 2 were used, in addition to some supplementary materials.

\subsection{Data Collection Tools}

A pre-test was developed to measure students' proficiency levels in using English tenses (present, past and future). The test included items to examine the use of present simple, present continuous, past simple, past continuous and simple future tenses with 'will' and 'going to'. This test consisted of 30 items divided into three main sections, each of which included 10 items. In the first section, students completed a short passage by selecting the best form of a given set of verbs; because the students did not need to generate any verbs or verb forms, this section was easiest. Second, students completed a short paragraph by writing the correct forms of 
given verbs; as the students needed to come up with the correct form themselves, this section was more difficult. The third section measured students' ability in forming yes/no questions and wh-questions in the different tenses; as it required students to generate both the sentences and the correct verb forms, this was the most demanding section. The face and content validity of the test was checked by three teachers, two of whom teach in the foundation programme at AOU-Oman and a third teacher who teaches in the Centre of Preparatory Studies at Sultan Qaboos University. Internal consistency reliability of the pre-test was 0.655 as measured by Cronbach's Alpha. The pre-test was also used as a post-test to measure the impact of the flipped classroom on students' grammar use.

A semi-structured interview was conducted with the students to explore their perceptions of the flipped methodology. A semi-structured interview was used because it is an appropriate method 'for the exploration of the perceptions and opinions of respondents regarding complex issues and for enabling probing for more information and clarification of answers' (Barriball \& While, 1994, p. 330). An interview guide was developed, including a general opening and a set of probing questions. Two language teachers from the foundation programme at AOU-Oman reviewed the questions for appropriateness and clarity.

\subsection{Flipped Classroom Videos}

Seven videos about English tenses were developed based on the planned lessons. Some research was done on YouTube to find suitable videos for the taught materials. Even though there were many videos on YouTube, the available videos were not suitable for the students. Some videos had complex language above the students' level, some of them used unclear examples and some included examples that were not related to students' experiences. It was then decided to design the videos to match the level of the students and the context of the study. The content of the videos was validated by an English teacher who teaches in the foundation programme at AOU-Oman. Table 2 shows the topics of the videos and the length of each video.

Table 2. Videos topics and length

\begin{tabular}{lll}
\hline Video & Topic & Length \\
\hline Video 1 & Present simple 1 & $7: 56$ \\
Video 2 & Present simple 2 & $6: 29$ \\
Video 3 & Adverbs of frequency & $5: 33$ \\
Video 4 & Present continuous & $7: 16$ \\
Video 5 & Past simple & $5: 27$ \\
Video 6 & Past continuous & $8: 08$ \\
Video 7 & Future & $9: 32$ \\
\hline
\end{tabular}

The videos were designed using computer software and iPad applications. First, the content was designed using Microsoft PowerPoint 2016. This was saved as a PDF file and then imported to Explain Everything - an iPad interactive whiteboard application - through which narration and laser effects were added. The videos were exported to iMovie, an iPad video editing software, in which the video was edited and background music was added. The final video was uploaded to YouTube for easy sharing with students via Edmodo.

\subsection{Lesson Plans}

Eight lesson plans were developed following Willis' (1996) framework of task-based language teaching. Willis' (1996) framework of task-based language teaching was selected based on recommendations by specialist developers of language teaching materials and language teaching professionals (Hung, 2014). The framework consists of three main phases: pre-task, task cycle and language focus. In the pre-task phase, students are introduced to the task and the topic (see Figure 1). The teacher in this phase provides task instructions, task materials and activates students' prior knowledge (Ting, 2016). According to Nunan (2004), schema building in the pre-task phase is vital because it 'serve[s] to introduce the topic, set the context for the task, and introduce some of the key vocabulary and expressions that the students will need in order to complete the task' (p. 31). Although the pre-task phase is very crucial for the success of the task, Willis (1996) argued that this phase should be the shortest stage - not more than 20 minutes. 


\begin{tabular}{|c|c|c|}
\hline \multicolumn{3}{|c|}{ Pre-Task } \\
\hline \multicolumn{3}{|c|}{ Introduction to topic and task. } \\
\hline \multicolumn{3}{|c|}{$\begin{array}{l}\text { Teacher explores the topic with the class, highlights useful words and phrases, helps students understand task } \\
\text { instructions and prepare. }\end{array}$} \\
\hline \multicolumn{3}{|c|}{ Task Cycle } \\
\hline Task & Planning & Report \\
\hline $\begin{array}{l}\text { Students do the task in pairs or } \\
\text { small groups. Teacher monitors } \\
\text { from a distance. }\end{array}$ & $\begin{array}{l}\text { Students prepare to report to the } \\
\text { whole class (orally or in writing). }\end{array}$ & $\begin{array}{l}\text { Students present or exchange their } \\
\text { reports and check them. }\end{array}$ \\
\hline \multicolumn{3}{|c|}{ Language Focus } \\
\hline Analysis & & Practice \\
\hline Students examine and discuss the & tures of the text. & ucts practice of the new feature. \\
\hline
\end{tabular}

Figure 1. Willis' Framework of Task-Based Language Teaching

During the second, task cycle phase, students do the task individually, in pairs or small groups. Willis (1996) divided this cycle into three parts: task implementation, planning, and report. In the task implementation part of the task cycle, task demands are, according to Ellis (2003), 'the processing demands imposed by the structure of the task on the language learner' (p. 67). These demands should be taken into deep consideration when designing lesson plans. Willis (1996) reported that task timing is a pre-requisite for task completion; thus, some tasks might take more than 15 minutes. In this stage (task cycle stage), the focus should be on fluency and meaning (Hung, 2014). In the final sub-stage of the task cycle phase, students report their answers so all students in the class can benefit from others' answers (Willis, 1996). This also creates a chance to give feedback, which fosters autonomous learning (Ting, 2016). The teacher's role in the task cycle phase is to monitor students, to make sure that students are working on the right task, to encourage students to participate in the task and to observe students (Willis, 1996).

The third phase, language focus phase is an important stage in task-based language teaching in which learners receive more practice on the language features highlighted by the task (Harmer, 2007). Nunan (2004) argued that freer practice is required in order for students to move beyond simple manipulation of language forms. Willis (1996) also emphasized the importance of language instruction in the last stage of his framework.

The designed lesson plans considered the previously stated arguments and followed the framework discussed above. Thus, each lesson plan included a pre-task, a task cycle and a language focus phase with analysis and practice. Each lesson plan was for two hours and the eight lessons were conducted overt a period of eight weeks. The following list shows the main learning objectives of the lessons:

1. Identify the grammar tenses used in context.

2. Know the meaning of grammar tenses used in different contexts.

3. Form accurate affirmative and negative sentences using different grammar tenses.

4. Produce accurate yes/no questions in the different tenses.

5. Produce accurate wh-questions in the different tenses.

6. Understand the time phrases used in English grammar tenses.

\subsection{Pre-Identification of Teaching Challenges}

While planning for the intervention, some challenges that might influence the intervention were identified and addressed by the researcher. The major anticipated challenge was students' inability to watch the videos before attending the class, which is a widespread issue with flipped classroom methodology (Basal, 2015; Lee \& Wallace, 2018). To address this challenge, videos were shared with the students two to three days before the class using Edmodo. Students were also allowed to transfer the videos to their flash drives before the class. Students' lack of awareness of the new flipped classroom methodology was anticipated as another challenge. Thus, students were provided with an explanation of the method and the process of the flipped classroom before the beginning of the intervention. While students were taking Level 2 (EF002), they would also be completing one course in information technology (IT) and another course in mathematics. As a result, it was anticipated that students might find it difficult to watch the videos and shared materials when they had competing tasks and 
homework for the other courses. Therefore, it was decided not to send videos to the students when they had IT or mathematics quizzes or assignments. To motivate students to watch the videos, the videos included example sentences from the real classroom. Various colours and attractive visuals were used with background music to raise students' motivation and interest.

\section{Results}

A three-point performance scale was developed to report and interpret the results of the pre-test and post-test based on the average score. Table 3 presents the five performance levels and the score range they represent. Based on the total score of the pre-test and post-test $(\max$ score $=30)$, the scale included three performance indicators: low, average and high.

Table 3. Performance level scale

\begin{tabular}{ll}
\hline Score Range & Performance Level \\
\hline $1.00-5.99$ & Very poor \\
$6.00-11.99$ & Below Average \\
$12.00-17.99$ & Average \\
$18.00-23.99$ & Above Average \\
$24.00-29.99$ & Excellent \\
\hline
\end{tabular}

Based on the performance scale, the students' performance on the pre-test was below average. Table 4 shows the results of the pre-test. Overall, the average score on the pre-test was $8.28(S D=3.14)$, with 16 being the maximum score and 2 being the minimum score. Looking at average scores for each section of the pre-test, the students' performance was low in all sections, although scores for Section 1 were higher compared to Section 2 and Section 3.

Table 4. Pre-test Scores

\begin{tabular}{lcc}
\hline Section & Mean & SD \\
\hline Section 1 & 5.59 (out of 10$)$ & 1.69 \\
Section 2 & $2.55($ out of 10$)$ & 1.89 \\
Section 3 & $1.4($ out of 10$)$ & 0.53 \\
\hline Total & $8.28($ out of 30$)$ & 3.14 \\
\hline
\end{tabular}

The results of the pre-test indicated that the majority of students demonstrated some basic understanding of English language tenses. However, they lacked the ability to form accurate sentences and questions in context. This was evident from the low scores of the second and the third sections of the pre-test. The low results of the pre-test were not attributable to the test conditions, such as classroom setting, exam time, invigilation and marking criteria, which were all well managed. However, the results could be attributed to the fact that the students were only capable of processing grammar at the level of recognition memory (recognizing the correct verb form in a list of forms in Section 1 of the test), and they were not able to process grammar in context when they needed to generate the verb form themselves (Section 2 of the pre-test) or generate whole sentences with the correct verb form without guidance (Section 3 of the pre-test). The pre-test gave a valid alarm that teaching should give more attention to question structure and grammar in context.

Although students scored better in the post-test, their performance remained belwo average. Table 5 shows the results of the post-test. The average score of the students in the post-test $(M=11.96, S D=4.84)$ was higher compared to the average score of the pre-test $(M=8.28, S D=3.14)$. Investigating the results closely, students performed better in the first section of the post-test $(M=6.21, S D=2.08)$ compared to the other sections of the test (Section 2: $M=3.18, S D=2.45$; Section 3: $M=2.73, S D=2.64$ ). 
Table 5. Post-test scores

\begin{tabular}{lcc}
\hline Section & Mean & SD \\
\hline Section 1 & 6.21 (out of 10) & 2.08 \\
Section 2 & $3.18($ out of 10$)$ & 2.45 \\
Section 3 & $2.73($ out of 10$)$ & 2.64 \\
\hline Total & $11.96($ out of 30$)$ & 4.84 \\
\hline
\end{tabular}

A paired-sample $t$-test was computed to compare the results of the pre-test and post-test and measure the effect of the intervention (Table 6). The statistical test revealed that there were significant differences between students' scores in the pre-test $(M=8.29, S D=3.14)$ and the post-test $(M=11.96, S D=4.84)$. These results indicate that the flipped classroom method had a positive effect on students' performance.

Table 6. Pre-test and post-test score comparison by $t$-test $(\mathrm{N}=28)$

\begin{tabular}{lcccc}
\hline Test & Mean & Standard Deviation & $t(27)$ & Significance \\
\hline Pre-test & 8.29 & 3.14 & -475 & .000 \\
Post-test & 11.96 & 4.84 & & \\
\hline
\end{tabular}

Four semi-structured interviews were conducted with four students to determine students' perceptions on the flipped classroom. Thematic analysis was used to analyse the interview data. Once the data was coded, three broad themes emerged: good aspects of the flipped classroom, issues with the flipped classroom and suggestions for improving the flipped classroom. Figure 2 shows the themes and subthemes that emerged from the interviews with the students.

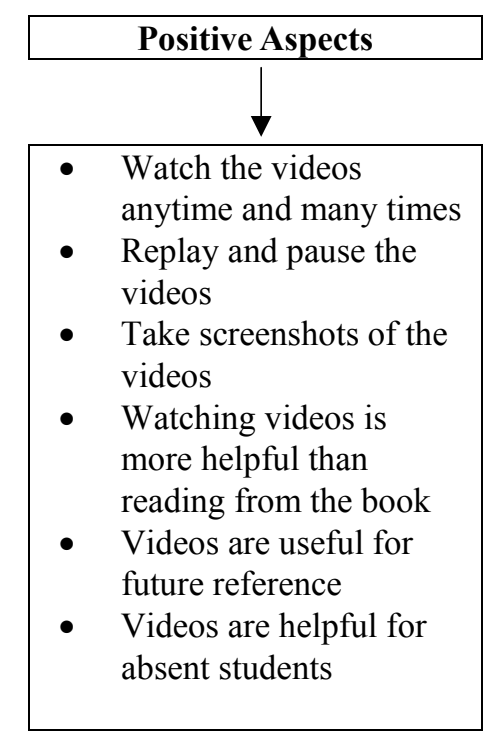

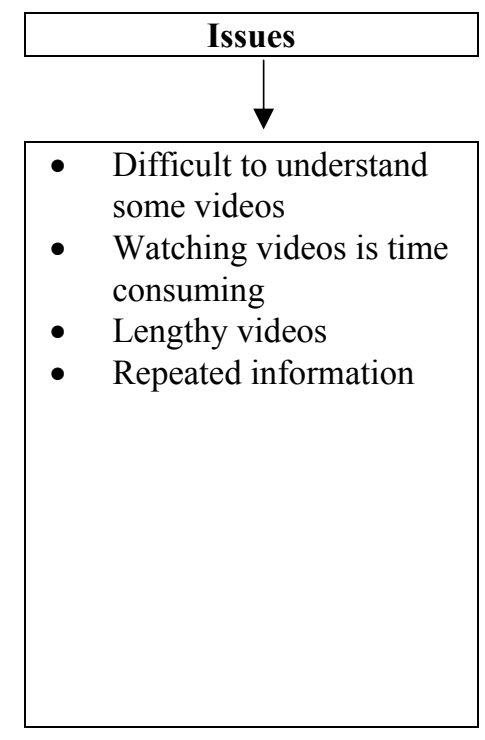

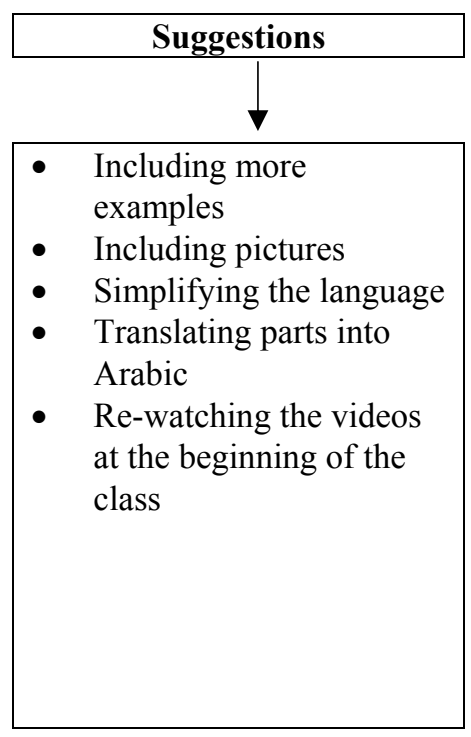

Figure 2. Emerging themes from students' interviews

The students described some positive aspects of the flipped classroom experience. The four students reported that flipped learning helped them prepare for the class. Student 1 explained that she could watch the videos at any time before the class. Student 3 supported this view by stating that she 'watched the video one day before the class and sometimes two days before the class'. Additionally, the students asserted that they watched the videos many times before the class. Student 2 confirmed that he watched some videos three to four times before the class. The four interviewed students liked the flipped classroom method because they could pause the videos and take notes at the same time. Student 3 stated, 'I stopped the video and I wrote more examples on my notebook'. 
Student 4 supported this view by mentioning that she took screenshots of the grammar rules presented in the video for her future reference. She added that she shared the images with her classmates. Further, Student 2 and Student 4 confirmed that watching videos was more helpful than reading the textbook to prepare for the class. Student 2 commented that videos are 'easy to understand and more interesting than reading from the book'. Furthermore, the majority of the interviewed students claimed that the videos were useful for their future reference. Student 4 stated, 'I downloaded all the videos from YouTube because I think they will help me in my future courses'. Finally, students reported that the videos were helpful for their classmates who missed the class.

Along with the positive aspects of the flipped learning approach, students encountered some issues. First, Student 2 stated, 'many of [their classmates] didn't watch the videos before the class'. Furthermore, they clarified that some struggling classmates were not able to understand the videos and lost motivation for watching the videos towards the end of the intervention. Student 3 revealed that her classmates always asked her to explain the videos to them in Arabic before the beginning of the class. In addition, the interviewed students expressed that watching videos was somehow time consuming. Two students (Student 2 and Student 3) claimed that some videos were lengthy, and some information was repeated in some videos. Students reported that they skipped some parts of the videos due to their length.

Students suggested different ideas to improve the practice of the flipped classroom. One of their suggestions was to include more examples in some videos. To make the videos more interesting, Student 3 recommended adding pictures to them. Student 1 stated that some parts of the videos should be simplified or translated into Arabic to help struggling students understand them. When asked about the duration of the videos, the four interviewed students suggested the videos should not be more than 5 minutes. To help students who were not able to watch the videos at home, Student 4 suggested viewing the videos at the beginning of the lesson in the class.

\section{Discussion}

This study aimed to explore the effects of the flipped classroom approach on Omani EFL learners' grammar proficiency and their perceptions of the flipped learning approach over the course of eight weeks. The results indicated that flipped learning had a positive impact on improving students' knowledge and usage of grammar. Although the mean scores of the post-test significantly improved, students' performed low in the section 1,2 and 3 of the test. This result could be attributed to the fact that some students, as it was reported in the interview, did not watch the videos before the class. This finding is consistent with those of Al-harbi and Alshumaimeri (2016), who found that the flipped classroom methodology played a positive role in developing Saudi secondary school students. Similar findings were reported in Lee and Wallace (2018) who reported higher average scores for students in the flipped classroom. Also, the result of this study matches the results obtained by Köroğlu and Çakır (2017) who found that the flipped classroom significantly enhanced students' grammatical competence in speaking skill. In addition, this study further supports the study of Obari and Lambacher (2015), which demonstrated a positive impact of flipped learning on students' English proficiency. This study also agrees with those Engin (2014) who showed that flipped learning improved students' language skills. A possible explanation for this result is that students could process the pre-class videos at their own place, and they could play the videos more than once for better understanding. Instead of spending a lot of class time lecturing, the class time was used productively for students to practice using the language (Herreid \& Schiller, 2013).

The results of this study indicate that students have a positive attitude towards the flipped learning approach because of its various benefits. These findings confirm previous research (Basal, 2015; Butt, 2014; El-Esery \& Radwan, 2017; Mehring, 2016; Perfume, 2015; Pudin, 2017; Saad ALRowais, 2014; Sun, 2017). Students in Basal's (2015) and El-Esery and Radwan's (2017) studies highlighted that the flipped classroom helped them to manage their study time and gave them the option to watch the videos at any time. Basal (2015) emphasised that watching videos prior to the class was very useful for students since this approach extended the time of learning. Similarly, Lee and Wallace (2018) reported that flipped learning extended EFL learners' exposure to the language. Moreover, the findings of this study are in line with Pudin's (2017) findings that students liked watching grammar video lessons and found them more engaging and useful than reading from the textbook.

This study, however, shed light on some issues with the flipped learning approach. Students reported that flipped learning could be time consuming and difficult. They also noted that the videos were lengthy. It can be assumed that the difficulty of the videos was related to some students' overall weak language level. This reason is supported by the fact that some students ceased watching the videos towards the end of the intervention period. These findings are similar to previous research on flipped learning. Basal (2015) reported that some of his students came to the class without watching the videos. Lee and Wallace (2018) showed that their students found flipped learning to be an additional burden. These issues could have negatively affected students' performance in 
the post-test in this study. Akshaya and Scholar (2019) stated that 'the success of a flipped classroom is closely related to students' enthusiasm for learning' (p. 12). Although it cannot be concluded that students in our study did not use the flipped classroom approach, the finding in this study that some students lost motivation to watch the videos contrasts with the finding of Lie and Yunus (2019), who claimed that flipped learning could enhance students' motivation to learn in ESL classrooms.

Students in this study provided different suggestions to improve the practice of the flipped classroom. They suggested including more examples and pictures in the videos and simplifying the language for weaker students. The video duration suggested by the students matched the video specifications identified by Akshaya and Scholar (2019), who recommended that ESL flipped learning videos should be 'short [and] under six minutes, so students feel the material is obtainable' (p. 10). In the same view, Basal (2015) limited flipped classroom videos to less than 15 minutes after the pilot stage of his research because students did not watch the lengthier videos before the class. Students' suggestions to watch the videos again in the class is not desirable and contradicts the flipped learning approach. However, the teacher can provide students with either a summary or an infographic that explains the grammar rule during the language focus in the lesson.

Some limitations need to be considered in this research. The major limitation of this study lies in the fact that it only uses one group in a quasi-experimental research methodology. It has only examined the flipped classroom using one element of classroom methodology, which is pre-class video-recorded lessons. The short duration of the intervention poses another limitation of the study. Although these limitations might affect the external validity of this research regarding generalising its results, its internal validity remains very high since the lesson plans, classroom teaching, testing, marking and statistical analysis were handled with high objectivity.

The study recommends that teachers should design appropriate and short videos that are very simple for students to understand and follow. The videos should include several examples related to the grammar rule. These examples should be supported by pictures to aid comprehension. In addition, teachers can use learning platforms, such as Moodle or Blackboard, where students can discuss the videos with their classmates before the class to help them understand the content.

A quasi-experimental study comparing the flipped classroom approach to conventional classroom approaches is recommended for future research. Large randomised controlled and lengthier trials could provide definitive evidence on the flipped classroom in the Omani context. Future research might also investigate the relationship between students' level of language proficiency, age and gender and the flipped classroom methodology.

\section{Acknowledgments}

The author expresses his gratitude to the teachers who reviewed the research instruments and the students at AOU-Oman who participated in the study.

\section{References}

Abeysekera, L., \& Dawson, P. (2016). Motivation and cognitive load in the flipped classroom: Definition, rationale and a call for research. Higher Education Research and Development, 34(1), 1-14. https://doi.org/10.1080/07294360.2014.934336

Akshaya, R., \& Scholar, M. P. (2019). Flipped Learning through Mobile Phones in ESL Classrooms. Language In India, 19(3), 9-13. http://www.languageinindia.com/march2019/valliammai/akshaya1.pdf

Al-harbi, S. S., \& Alshumaimeri, Y. A. (2016). The flipped classroom impact in grammar class on EFL Saudi secondary school students' performances and attitudes. English Language Teaching, 9(10), 60-80. https://doi.org/10.5539/elt.v9n10p60

Alexander, B., Adams Beker, S., Cummins, M., \& Hall Giesinger, C. (2017). Digital Literacy in Higher Education, Part II: An NMC Horizon Project Strategic Brief. (pp. 1-37). The New Media Consortium. https://doi.org/10.4135/9781483346397.n97

Andujar, A., Salaberri-Ramiro, M. S., \& Martínez, M. S. C. (2020). Integrating flipped foreign language learning through mobile devices: Technology acceptance and flipped learning experience. Sustainability, 12(1110), 1-12. https://doi.org/10.3390/su12031110

Arifani, Y. (2019). The application of small WhatsApp groups and the individual flipped instruction model to boost EFL learners' mastery of collocation. CALL-EJ, 20(1), 52-73.

Barriball, L., \& While, A. (1994). Collecting data using a semi-structured interview: A discussion paper. Journal of Advanced Nursing, 19, 328-335. https://s3.amazonaws.com/academia.edu.documents/34291860/Barriball While_1994_Collecting_data_u 
sing_a_semi-structured_interview_JAN.pdf?AWSAccessKeyId=AKIAIWOWYYGZ2Y53UL3A\&Expires $=1559328875 \&$ Signature $=7 \mathrm{aVNErUPN74GhPXUIUpVwQ8cOB0 \% 3D \& response-content-disp}$

Basal, A. (2015). The implementation of a flipped classroom in foreign language teaching. Turkish Online Journal of Distance Education, 16(4), 28-37. https://doi.org/10.17718/tojde.72185

Bauer-ramazani, C., Graney, J. M., Marshall, H. W., \& Sabieh, C. (2016). Flipped learning in TESOL: Definitions, approaches, and implementation. TESOL Journal, 7, 429-437. https://doi.org/10.1002/tesj.250

Bennett, N., \& Lemoine, G. J. (2014). What VUCA really means for you. Harvard Business Review, 92(1/2).

Bereiter, C. (1994). Constructivism, socioculturalism, and popper's world 3. Educational Reseaecher, 23(7), 21-23. https://doi.org/10.3102/0013189X023007021

Bergmann, J., \& Sams, A. (2012). Flip your classroom: Reach every student in every class every day. Teaching Theology \& Religion, 17(1). https://doi.org/10.1111/teth.12165

Bishop, J., \& Verleger, M. (2013). Testing the flipped classroom with model-eliciting activities and video lectures in a mid-level undergraduate engineering course. 2013 IEEE Frontiers in Education Conference, (FIE), 161-163. https://doi.org/10.1109/FIE.2013.6684807

Brame, C. (2013). Flipping the classroom. Vanderbilt University Center for Teaching. http://cft.vanderbilt.edu/guides-sub-pages/flipping-the-classroom/

Butt, A. (2014). Students' views on the use of flipped classroom: Evidence from Australia. Business Education and Accreditation, 6(1), 33-44.

Carhill-Poza, A. (2019). Defining flipped learning for English learners in an urban secondary school. Bilingual Research Journal, 42(1), 90-104. https://doi.org/10.1080/15235882.2018.1561552

El-Esery, A. M., \& Radwan, N. A. (2017). Modeling CALL programs in EFL flipped classrooms to enhance achievement and language learning attitude. Journal of Research in Curriculum, Instruction and Educational Technology, 3(2), 115-126. https://doi.org/10.12816/0042042

Ellis, R. (2003). Designing a Task-Based Syllabus. RELC Journal, 34(1), 64-81.

Engin, M. (2014). Extending the flipped classroom model: Developing second language writing skills through student-created digital videos. Journal of the Scholarship of Teaching and Learning, 14(5), 12-26. https://doi.org/10.14434/josotlv14i5.12829

Eppard, J., \& Rochdi, A. (2017). A framework for flipped learning. Proceedings of the 13th International Conference on Mobile Learning 2017, 33-40.

Han, Y. (2015). Successfully flipping the ESL classroom for learner autonomy. NYS TESOL Journal, 2(1), 98-109.

Harmer, J. (2007). The Practice of English Language Teaching. Pearson Longman.

Herreid, C. F., \& Schiller, N. A. (2013). Case studies and the flipped classroom. Journal of College Science Teaching, 42(5), 62-66.

Hung, N. V. (2014). Review of notion and framework of task-based language teaching. International Journal of English Language and Linguistics Research, 2(1), 39-48.

Johnson, P. (2009). The 21st century skills movement. Educational Leadership, 67(1), 11. http://ipkt.org:8080/modul/DPLI/index_htm_files/21ST CENTURY SKILLS.pdf

Köroğlu, Z. Ç., \& Çakır, A. (2017). Implementation of flipped instruction in language classrooms: An alternative way to develop speaking skills of pre-service English language teachers. International Journal of Education and Development Using Information and Communication Technology, 13(2), 42-55.

Kurt, G. (2017). Implementing the flipped classroom in teacher education: Evidence from Turkey. Educational Technology and Society, 20(1), 211-221.

Kvashnina, O. S., \& Martynko, E. A. (2016). Analyzing the potential of flipped classroom in ESL teaching. International Journal of Emerging Technologies in Learning, 11(3), 71-73. https://doi.org/10.3991/ijet.v11i03.5309

Lane-Kelso, M. (2015). The pedagogy of flipped instruction in Oman. Turkish Online Journal of Educational Technology, 14(1), 143-150.

Lee, B. (2017). TELL us ESP in a flipped classroom. Eurasia Journal of Mathematics, Science and Technology 
Education, 13(8), 4995-5007. https://doi.org/10.12973/eurasia.2017.00978a

Lee, G., \& Wallace, A. (2018). Flipped learning in the English as a foreign language classroom: Outcomes and perceptions. TESOL Quarterly, 52(1), 62-84. https://doi.org/10.1002/tesq.372

Lie, W. W., \& Yunus, M. M. (2019). Flipped for a betterment: The acceptance level towards flipped learning among Malaysian ESL learners. Journal of Education and Development, 3(1), 69. https://doi.org/10.20849/jed.v3i1.569

Marshall, H. W., \& DeCapua, A. (2013). Making the transition to classroom success: Culturally responsive teaching for struggling language learners. Ann Arbor: University of Michigan Press. https://doi.org/10.3998/mpub.4625213

Mcnally, B., Chipperfield, J., Dorsett, P., Del, L., Valda, F., Sandra, F., Reddan, G., Roiko, A., \& Rung, A. (2017). Flipped classroom experiences: Student preferences and flip strategy in a higher education context. Higher Education, 73(2), 281-298. https://doi.org/10.1007/s10734-016-0014-z

Mehring, J. (2016). Present research on the flipped classroom and potential tools for the EFL classroom. Computers in the Schools, 33(1), 1-10. https://doi.org/10.1080/07380569.2016.1139912

Nunan, D. (2004). Task-Based Language Teaching. Cambridge University Press.

Obari, H., \& Lambacher, S. (2015). Successful EFL teaching using mobile technologies in a flipped classroom. Critical CALL-Proceedings of the 2015 EUROCALL Conference, Padova, Italy, 433-438. https://books.google.com.om/books?hl=en\&lr=\&id=GgEvCwAAQBAJ\&oi=fnd\&pg=PA433\&dq=oba

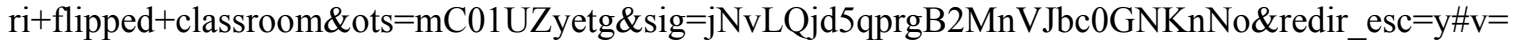
onepage $\& \mathrm{q}=$ obari flipped classroom $\& \mathrm{f}=$ false

Olusegun, S. (2015). Constructivism learning theory: A paradigm for teaching and learning. IOSR Journal of Research \& Method in Education Ver. I, 5(6), 66-70. https://doi.org/10.9790/7388-05616670

Perfume, Y. E. (2015). Exploring a Flipped Classroom Approach in a Japanese Language Classroom: A Mixed Methods Study. [Ed.D. dissertation, Baylor University]. ProQuest LLC.

Pierce, R., \& Fox, J. (2012). Vodcasts and active-learning exercises in a "flipped classroom" model of a renal pharmacotherapy module. American Journal of Pharmaceutical Education, 76(10), 1-7. https://doi.org/10.5688/ajpe7610196

Pudin, C. S. J. (2017). Exploring a flipped learning approach in teaching grammar for ESL students. Indonesian Journal of English Language Teaching and Applied Linguistics, 2(1), 51-64. https://doi.org/10.21093/ijeltal.v2i1.47

Saad ALRowais, A. (2014). The impact of flipped learning on achievement and attitudes in higher education. International Journal for Cross-Disciplinary Subjects in Education, 4(1), 1914-1921. https://doi.org/10.20533/ijcdse.2042.6364.2014.0266

Sun, Y. C. (2017). Flipping every student? A case study of content-based flipped language classrooms. E-Learning and Digital Media, 14(1-2), 20-37. https://doi.org/10.1177/2042753017692428

Ting, J. (2016). A lesson plan of TBLT (Task-Based Language Teaching). International Journal of Secondary Education, 4(3), 1-7. https://doi.org/10.11648/j.ijsedu.20160403.12

UNESCO. (2014). Position Paper on Education Post-2015. https://unesdoc.unesco.org/ark:/48223/pf0000227336

Willis, J. (1996). A Framework for Task-Based Learning. Longman Limited.

\section{Copyrights}

Copyright for this article is retained by the author(s), with first publication rights granted to the journal.

This is an open-access article distributed under the terms and conditions of the Creative Commons Attribution license (http://creativecommons.org/licenses/by/3.0/). 